\title{
The Role of the Educational Discussion in the Development of the Unprepared Foreign-Language Speech Skills
}

\author{
Farida I. Yarullina $^{1} \&$ Rustam M. Fakhretdinov ${ }^{1}$ \\ ${ }^{1}$ Kazan (Volga region) Federal University, Kazan, Russia \\ Correspondence: Farida Iskandarovna Yarullina, Kazan (Volga region) Federal University, Kremlevskaya Street, \\ 18, Kazan 420008, Russia. E-mail: yarullina-f@mail.ru
}

$\begin{array}{lc}\text { Received: April 14, } 2015 & \text { Accepted: April 20, } 2015 \quad \text { Online Published: April 27, } 2015 \\ \text { doi:10.5539/jsd.v8n4p45 } & \text { URL: http://dx.doi.org/10.5539/jsd.v8n4p45 }\end{array}$

\begin{abstract}
The relevance of the problem under study is determined by the transition to active methods in the foreign languages teaching which is observed in recent years. These methods also include the educational discussion which is a subject of this research. The purpose of the article is to identify the educational potential of the educational discussion as one of the methods of formation and development of the unprepared speech skills and an effective means of the communicative competence formation in the foreign languages teaching. Based on the analysis of different approaches to the problem of teaching the unprepared foreign language speech, as well as the results of practical work, the authors of the article identify such features as spontaneity, naturalness and motivation. Authors come to the conclusion that the objective features of this type of speech activity being the properties of the educational discussion must be taken into account in the organization of the educational process aimed at the development of the free conversation skills in a foreign language. The need for the material selection and structuring for the organization of the educational discussion in accordance with its linguistic and cultural value is highlighted in the article. It also includes the tasks which are recommended for students to perform at the preparation stage of the discussion in order to overcome language and speech difficulties and the types of the educational discussions used in foreign language teaching are defined. In general according to the results of research such method of teaching as educational discussion is effective for the formation and development of unprepared speech skills in a foreign language. The article may be useful for the teachers of a foreign language working at secondary schools and in higher educational institutions, also for students, graduate and postgraduate students who are engaged in studying and research of the problems of the foreign languages teaching.
\end{abstract}

Keywords: language education, formation of a linguistic identity, communicative competence, the educational discussion, the unprepared speech, development of the unprepared foreign-language speech skills, motivation of speech activity, the choice of content of the statement, the choice of linguistic means of expression, intuitive search of verbal behavior

\section{Introduction}

Nowadays in the era of globalization requirements to the level of foreign language proficiency for university graduates are high. This level as the basis of professional competence must comply with international requirements and standards and increase competitive advantage of a specialist in working market both at home and abroad.

The main objective of language education is the formation of a multicultural linguistic identity that has a high level of foreign language communicative competence. In general communicative competence can be considered as the ability to speech interaction with the interlocutor based on readiness for communication and communication technique. In our opinion, foreign language communicative competence can be characterized as ability of the identity to understand and create statements in a foreign language in different situations in compliance of linguistic and social rules which are held by native speakers.

The structure of communicative competence includes several interrelated components that are interconnected, forming thereby the integrity and unity. For this reason the concept "communicative competence" can be considered as a system concept. There are different classifications of communicative competence components in the works of domestic and foreign researchers, the analysis of which allows us to distinguish the following 
components: 1) linguistic competence, 2) sociolinguistic competence, 3) social competence, 4) strategic competence, 5) discursive competence, 6) social competence (Shchukin, 2004).

Interaction of all communicative competence components is necessary for the successful realization of the communication process and the formation of communicative competence when teaching a foreign language. However, particular importance is attached to two components, which are socio-cultural and discursive competences. The socio-cultural component represents readiness and ability to conduct dialogue of cultures which is supposed to be knowledge of the own culture and the culture of the target country. Discursive competence is a coherent and logical statement of its position, readiness to conduct dialogue or discussion, to evoke a response of the interlocutor engaging him in communication (Galskova, 2006). Not only the language but its expressional opportunities, the behavior of the speaker in terms of communication became the subject of education as a result of gradual transition to the communication-oriented teaching. R.P. Milrud, a famous methodologist in the foreign languages teaching, notes: "The behavior of the speaker in terms of communication is understood ... as an active and activity realization of linguistic, psychological and socio-cultural knowledge which is important for students for effective foreign-language communication today. This knowledge includes language acquisition as a discourse that is a way of a thought formation in the text. Such knowledge means possession of ways of thinking and creation of oral and written texts ..., considering individual and psychological features of participants of communication and their socio-cultural experience" (Milrud, 2004).

Due to the fact that foreign language communicative competence is expressed in the ability to communicate free in a foreign language in real life situations, the formation and development of such necessary skills are very important for students. Educational discussion is a teaching method of unprepared speech skills and one of the most important forms of educational activities that promote initiative of students. Communication as a part of the discussion encourages its participants to seek various ways to express their thoughts, increases susceptibility to new information, a new point of view. The more students are accustomed to think proceeding from their clear obscures, the greater is their creativity (Cell, 1984). Educational discussion in information transfer is of course less effective than monologue presentation of the learned material, but it is highly important for information fixing, creative thinking of the learned material and the value systems formation (Klarin, 1997).

\section{Methods}

The following issues are discussed in the research: 1) identifying objective features of the unprepared speech as a type of speech communication; 2) determination of educational discussion properties as a teaching method of the unprepared foreign-language speech; 3) the analysis of the materials used for preparation and holding an educational discussion in class for teaching of the unprepared foreign-language speech; 4) the analysis of the tasks offered to students at a stage of educational discussion preparation; 5) the analysis of psychological aspects of communication and types of educational discussion; 6) the analysis of the existing points of view told by different researchers on the problem of educational discussion and the unprepared foreign-language speech.

The following theoretical methods were used to achieve a goal and the solution of the research problems: the system oriented analysis of psychological and pedagogical, scientific and methodical literature on the research problem; studying and generalization of innovative pedagogical experience in professional language training of students; analysis, synthesis.

Theoretical and methodological basis of the research were primarily works of domestic methodologists and psychologists as Gurvich (1964), Rakhmanov (1990), Obnosov (2012), Vaisburd (2003), Zaretskaya (2002), Morozova (2010), Zimnyaya (2007), Leontjev (2004) which have been engaged in the study of problems of oral speech teaching in a foreign language. The study also includes the analysis of works of foreign authors on the problems of the educational discussion and the unprepared speech (Smith, 1978; Davis-Seaver, 1988; Thome and Reinhardt, 2008).

\section{Results}

\subsection{Characteristics of the Unprepared Speech and Properties of the Educational Discussion}

Educational discussion is the most difficult and integral type of the unprepared speech. It is confirmed by the provisions in the works of the leading domestic and foreign psychologists and methodologists whose opinions we support completely and share in our research. It is possible to define this form of educational activity as the purposeful, collective discussion of a specific problem which is followed by an exchange of ideas, opinions and judgments. There is a natural and lively dialogue when using educational discussion in teaching foreign languages as discussion is not possible to prepare in advance. At the same time, we believe that it cannot be recommended as the basic final work on speech skills because it is difficult to regulate and control it. These 
properties of the discussion are one of the main objective characteristics of an unprepared speech, which, unfortunately, quite often remains outside the attention of some methodologists and teachers, that is, it is not used in class for the development of speech skills and the ability to communicate in a foreign language, or is considered as something secondary.

It is known that an intelligent human performance always assumes a choice of several possibilities. For this reason the choice of the content of the utterance and linguistic means of expression cannot be limited by the educational requirements during the work on the unprepared speech as it is connected with mental activity in actual practice. Spontaneity is the leading characteristic of unprepared speech and it must be observed as much as possible in the learning process.

Memory is of great importance when working on the speech. It promotes memorization of linguistic forms and at the same time mastering methods of communication. It is considered that the more independence is shown by the person in the implementation of a specific action, the better efficiency of incidental memorizing is. In this case it is about memorizing without attitude on it. These provisions are fundamental when working on unprepared speech.

Any human activity including speech is determined by a combination of motives. The motivation of activity is a realization of its necessity and expediency and also in anticipation of satisfaction from its implementation. As a result, there is an interest to this work and the need for correct performance.

The motivation of speech activity in foreign language lessons leads to a favorable, psychologically comfortable situation both in class and in educational process in general. If the student manages to overcome himself, he starts to respect and believe in himself. Student chooses how and what to say, who and what to ask, with whom to argue or to agree when speaking. In such situation students feel more free and relaxed. It improves the psychological climate in the class, increases spontaneity and motivation of utterances, promotes successful second language acquisition in an educational situation.

Speaking about motive of speech activity, it is necessary to emphasize the value of its reality. Long work with language without real speech activity leads to formation of the corresponding speech stereotypy. We are convinced that activity and interest in it must be actual, therefore discussion may become that type of study which will develop skills of unprepared speech communication.

There have been suggested some ideas in the works of some psychologists and methodologists that as motive for the speech activity can serve a state of anxiety that is the negative emotionally colored motive. In this case student is interested not in the result but what impression he would leave on a teacher and the members of the study group. In this situation a teacher should make a greater effort to create an atmosphere of goodwill, as communication, especially in a foreign language, is almost impossible in conditions of stress and fear. It is necessary to remember that speech activity in a foreign language is a difficult type of practical activities, and it is impossible to avoid making mistakes during its performance.

All of the aforesaid indicates that during the work on the unprepared speech skills it is important that communication should be quiet as far as it is possible, the motive of communication should be the most real, and speech communication should provoke interest in all attendees. It is also important that positive emotions should prevail in class, but not a state of anxiety, there should be the possibility of intuitive search, selection and correcting verbal behavior.

\subsection{The Selection of Material for the Organization of Educational Discussion and Preliminary Work on It}

The provisions mentioned above suggest that the activity which is the most corresponding to problems of development of the unprepared speech skills is conversation based on a fiction as it can most implicitly, comprehensively and emotionally give the mediated idea of socio-cultural and sociolinguistic features of life of the country of the spoken language. Second language mastering is impossible without knowledge of these features as means of cross-cultural communication. Views on the literary text as on optimal material for initiating of unprepared speech were expressed by many scientists. So, for example, Z.I. Klyuchnikova in the works proves that reading serves the development of intellect, emotional side and language of the individual and it is an effective way of introduction of material in class to develop the unprepared speech skills (Klyuchnikova, 1973).

However it should be noted that conversation can be organized on the basis of other authentic materials such as original publicistic texts, documentary and feature films, materials from the Internet for the selection of which the main criterion is their linguo-cultural studying and cultural value. Formation of communicative competence in the course of learning foreign languages is possible only on the basis of cultural background knowledge which characterizes this or that culture, knowledge relating to history, mentality, traditions of everyday life of the 
people of the country of the spoken language. Retrieval of culture study information from training materials helps to form a foreign worldview.

Nowadays materials from the Internet used in the educational process have a great advantage. They allow to obtain information by ear and visually. They are characterized by accessibility, actuality and novelty, as well as linguistic and cultural diversity.

New information technologies make it possible to put into practice socio-cultural and competency-based approach in teaching foreign languages, they create a virtual cultural and linguistic space. They help students to develop their self-organization and creativity.

The application of information technologies promotes the formation of not only foreign language communicative competence, but also the information competence of students which is shown in using the new information technologies, in understanding the range of their application, as well as a critical attitude towards the disseminated information. All these increase the interest and the motivation of learning a foreign language.

Before the organization of educational discussion after reading the text or viewing film we always suggest that students perform certain tasks which represent the exercises in the prepared speech directed at overcoming difficulties. As a rule, it is the following tasks: to break the read text into semantic parts and to make a plan, to present briefly in an oral form the text content or a plot of the film, to retell the text or to present a film's plot by keywords, to retell the text on behalf of different characters, to write questions to the text or a plot of the film, to present the content or a plot seen in dialogue. A useful exercise in the prepared speech is compression of the plot to a certain number of sentences. Such exercises as definition of the main ideas of the text or film, generalization and discussion of read or seen in a dyad close as much as possible to exercises in the unprepared speech. They promote training of a syntactic sentence structure, relationship between sentences, brevity and the precision of thought expression.

All educational work anticipating free speech communication is mainly aimed at a psychological nature. For example, reading serves the extraction of information from the text at the semantic level, a plan allows to divide information into semantic groups followed by the identification of meaningful points, a summary of the text according to the plan is the final phase of mental activity, and from the psychological point of view, aims at making each participant of forthcoming communication confident that the source material for conversation is understood correctly, and thereby to eliminate the possible state of anxiety. Study is mainly the language oriented and serves creating favorable conditions for conversation. We believe that the task on writing questions is optional. It depends on the level of language proficiency of students. Work in pairs is also optional and it serves as a kind of warmer before the general discussion especially at the initial stage and in groups of students whose level of language knowledge is lower.

Competent selection of the training material in a foreign language, detailed development and compilation of exercises in the prepared speech on the basis of the selected material, preparation of creative tasks for the organization of the discussion, all this is undoubtedly necessary for that foreign language speech communication within a certain situation was really successful. But, in our opinion, in this case the teacher's knowledge of the features of communication psychology is also important as we suggest teaching foreign language speech activity through communication.

\subsection{Types of Educational Discussion and Psychology of Communication}

In this regard it would be desirable to tell a few words about psychological aspect of the problem situation. We believe that existence of the problem situation does not yet mean speech act. Orienting in it leads to the analysis of conditions of communication, sets a goal of communication and defines possibility of its achievement. Then communicative intension is formed. If the speech way of action is chosen, there is an internal programming of the utterance, after that appear an internal scheme of a communication language form and verbalization. This chain of orientation under the influence of a problem situation should not be broken during the study as possible. The introduction of purposes in terms of language and the content leads to violation of naturalness of the solution of a problem, therefore, the developed skills cannot be natural. It means only experience of verbal behavior can help to develop confidence in communication.

It should not be forgotten that there are also nonverbal components of orientation in the situation, for example, orientation in spatial communication conditions. It is known that for speech communication it is good when participants are located so that they could speak and listen without tension seeing each other. An arrangement of participants of discussion in a circle that we try to adhere on our classes is considered optimal.

Good organization and the success of the discussion on the lesson in a foreign language depend, first of all, on 
the teacher. Speaking about the personality of the teacher conducting a course of a foreign language, psychologists and methodologists emphasize the following psychological qualities which teacher should possess: sociability, tactfulness, ability to control the emotions, attentiveness, creativity, sense of humour, flexibility of thinking, activity. We join this characterization and believe that a teacher certainly has to promote establishment on classes in speech practice of a quiet, businesslike and friendly environment. It is unacceptably that the personality of the teacher suppressed the students, depriving them of an initiative and substituting natural motives of communication by anxiety.

Educational discussion with the teacher as the leader is the most common practice in the teaching foreign language. This type of discussion is known as an evolving discussion that is growing out of more traditional forms of academic work. In addition, there are discussions with the student in the role of the leader and the so-called self-organizing discussion that takes place without the participation of the leader.

By holding discussions sometimes we use a dynamics technique of the process of creative thinking that was offered by Jane Davis-Seaver and called "Chaos in the Classroom." The essence of this technique is to advance from a single point of view to the problem under discussion to learn at the edge of chaos, when there are many points of view, discussion is developing in different directions and learners listening to other's opinions develop their own judgments. In this case the role of a teacher is to monitor the course of reasoning and switching the learning process from one level to another. As a result, understanding the problem becomes versatile, deeper interest and motivation to learn are created by a group's power but not the diligence of a teacher. Trying to develop creative abilities of the students, we do not aim at extirpation of the chaos, we want to find the relation between order and disorder, which would appear to be the most effective in order to leave the stereotypes in evaluating problems, to try all the possible solutions, look at the problem from a new point of view. Using the discussion method of American researcher, we proceed from the theory of self-organization, the theory of synergy, according to which a state at the edge of chaos may be the most productive for the birth of a new order which is not dictated by a teacher and is born spontaneously.

\section{Discussion}

The use of educational discussion as one of the most effective methods of teaching foreign language is considered by many psychologists and methodologists. The analysis of the works of these researchers shows that among them there is a single point of view on many aspects of the problem that we share in our study.

Consensus is shown in the definition of the discussion as the consideration of any controversial issue, as well as the allocation of argumentation as its main characteristics, or each side argues its position discussing controversial issue, proving or rejecting provisions.

Speaking about the organization of the discussion sessions the researchers point three stages which have different names by different authors. The first stage is the preparation for discussion when the subject and purposes of the discussion are determined, the leader is elected, the regulations and the sequence of questions under discussion are defined. Researchers agree in opinion that the preparatory stage is extremely important. In study in the language immersion is possible only working with specially selected and methodically organized material which have to be worked out to overcome difficulties before the discussion in a preparatory stage, the necessary lexical items and grammatical structures have to be studied and fixed, the content of the material has to be analyzed. The next stage is the discussion when participants perform, answer the arising questions. The final stage is the summing up: an analysis of the results of the discussion, evaluation of the role of the leader and performances of students, coordination of opinions, the joint formulation of the problem solution.

Unified viewpoint is expressed by researchers in determining the functions of educational discussion. The discussion in foreign language lessons as an element of the course is different from the discussions taking place in real life especially by the purposes. Here it is not so important to find a solution of some problem as acquire certain language skills, to use and fix the existing knowledge and skills in the language.

In this case the discussion serves as learning function. The second function is development function and is connected with the stimulation of creative activity of students, with the development of their logical abilities, the ability to think independently, to argue and to prove the point of view. The third educational function is the formation of social competence of students. During the discussion students learn to reach agreement on certain issues, to develop overall strategy and tactics, sometimes to give way and to compromise. The extremely important ability forming during discussions is the ability to listen to the opponent, to respect his opinion and to try to understand his arguments.

Researchers concur in determining the properties of educational discussion such as naturalness, spontaneity and 
motivation. Finally, they agree in opinion that the discussion can be used in foreign language teaching both as a method and as a form, i.e., it can be carried out within the other activities being their element. For example, the method of discussion along with role-playing games may precede a method of projects or to be the part of the design work.

Similar unanimity of opinions is not observed in the works devoted to research of the problem of formation and development of the unprepared speech skills. The actual content of unpreparedness of the speech is understood by different researchers differently. So, for example, P. B. Gurvich (1964) highlights three aspects of unpreparedness of the speech as combinational unpreparedness, that is the ability to combine newly earlier acquired speech and language units; spontaneous and initiative character of the speech, that is lack of a call of the utterance from the outside, for example, a retort of the interlocutor and, at last, unpreparedness in time, the so-called impromptu.

These signs of the unprepared speech are defined by N. S. Obnosov (2012) in a different way. He allocates only two aspects: initiative character of speech and quick response to the utterance of the interlocutor. The point of view of N. S. Obnosov has the right for existence though he does not allocate such important aspect, in our opinion, as a combining. Obviously, the author assumes that ability to combine speech material arises on its own. We believe that this assumption is wrong. It is contradictory for the reason that in the works N. S. Obnosov as many other researchers characterizes the unprepared speech as a creative process. Creative character of the unprepared speech is shown in a combining that is an ability to use speech material in a new situation. But ability to transfer speech material in new environment is not shown as such, it needs to be specially developed. We believe that educational discussion possesses the high training potential for this purpose.

There are statements of the certain researchers in methodological literature rejecting the second aspect of unpreparedness of speech presented in P. B. Gurvich's definition (1964). These are the researchers who hold to an opinion that the dialogue and the unprepared speech are closely related. They consider that statements in the discussion of the question are often reactive as well as dialogue remarks because interlocutors talk to each other, reacting to statements of the partner not knowing what he will say and with no time for preparation. We support this point of view and believe that the dialogical speech can be considered as possibility of formation of the unprepared speech skills.

\section{Conclusion}

So, in the context of globalization in the XXI century an acquisition of high level foreign-language communicative competence is becoming important. It is expressed in pursuance and ability constantly to receive valuable knowledge, to change behavior and the attitude towards other culture so that to show flexibility and openness in dialogue with representatives of other linguistic social medium (Davisetal, 2009).

Unfortunately, in the system of professional language education in our country dominates the traditional model of foreign languages teaching which, in our opinion, is in general unable to solve the problem of high quality of preparation and competitiveness of graduates of the higher school. Reproductive style of teaching, undoubtedly, has to stay in the past. It is necessary to pass on a new education system which would provide development of cognitive activity and independence of thinking of students, ability to study continuously and to gain independence both in the sphere of professional activity and in the sphere of universal human values. We believe that the creative teaching meets the requirements of a modern era including various interactive methods of teaching as educational discussion (Ostroumov and Ostroumova, 2013).

As it was noted above, formation of communicative competence is the main objective of foreign language teaching. A significant role has the development of the unprepared speech skills by use of such technique of teaching as educational discussion. For holding a successful discussion Participants have to possess certain knowledge of a subject of discussion, have communication culture, be able to build the statements according to a communication situation, understand the speech of interlocutors, to correlate their positions to the opponents' position.

In the preparation and the organization of discussion in a foreign language lesson the teacher plays an important role and has to possess for this purpose certain psychological qualities and be able to support the initiative of students to communication.

Educational discussion is one of interactive methods of teaching which can be characterized as methods of interaction of participants of educational process and the teaching which is carried out by the use of these methods can be considered interactive, that is built on the interaction. Interactive methods of training are among innovative methods. Of course, they promote the activation of cognitive activity of students and independent 
acquisition of a training material that has the special professional importance for students of higher education institutions as it conducts to development of the skills necessary not only for implementation of foreign-language communicative activity, but also for self-education in the field of a foreign language. One of the important qualities of the linguistic identity is the ability and readiness for independent (autonomous), conscious learning of language and, therefore, culture of the country the language is spoken. And according to D. Little "ability to an autonomy is shown both in a way of the learning and in a way of transfer by the student of results of the learning on wider context" (Little, 1991). The above statements allow us to recognize that development of an educational autonomy of students acts as one of the purposes of professional acquisition of a foreign language in the context of the personal focused approach in teaching.

Finally, it should be noted that the issues concerning the influence of interactive forms of work including free discussion over increase of level of an educational autonomy of students can determine the direction of our further research work.

\section{Acknowledgments}

The work is performed according to the Russian Government Program of Competitive Growth of Kazan Federal University.

\section{References}

Cell, E. (1984). Learning to learn from Experience. Albany, 204.

Clarin, M. V. (1997). Innovatsii v obuchenii: metafory i modeli: Analiz zarubezhnogo opyta. Moscow, 223.

Davis- Seaver, J. (1988). Promoting Critical Thinking at the University Level. National Forum of Teacher Education, 3, 15-27.

Davis, N., Fletcher, J., \& Groundwater-Smith, S. (2009). The Puzzles of Practice: Initiating a collaborative research culture. Australian Association for Research in Education. International Education Research Conference. Australia, Canberra. Retrieved from www. aare.edu.au//09pap/dav091506.pdf

Galskova, N. D., \& Gez, N. I. (2006). Teoriya obucheniya inostrannym yazykam. Lingvodidaktika i metodika. Moscow, 336.

Gurwich, P. B. (1964). Obuchenie nepodgotovlennoj rechi. Inostrannye yazyki v shkole, 1, 3-19.

Leontjev, A. A. (2004). Psikhologiya obshheniya. Moscow, 456.

Little, D. (1991). Learner Autonomy : Definitions, Issues and Problems. Dublin, 215.

Milrud, R. P. (2004). Aktualnye problemy metodiki obucheniya inostrannym yazykam za rubezhom. Inostrannye yazyki $v$ shkole, 3, 34-40.

Morozova, I. G. (2010). Ispolzovanie diskussii na zanyatiyakh inostrannogo yazyka v ramkakh problemnogo obucheniya pri podgotovke sovremennykh spetsialistov. Inostrannye yazyki. Teoriya i praktika, 1, 25-35.

Ostroumov, A. I., \& Ostroumova, O. F. (2013). Kreativnost' i kreativnoe obuchenie kak slagaemye modernizatsii obrazovaniya $\mathrm{v}$ Rossii. Istoricheskie, filosofskie, politicheskie i yuridicheskie nauki, kul'turologiya i iskusstvovedenie. Voprosy teorii i praktiki. Tambov: Gramota, 2(28), 149-153.

Rakhmanov, I. V. (1990). Obuchenie ustnoj rechi na inostrannom yazyke. Moscow, 120.

Smith, I. (1978). Teaching with Discussions: Review. Educational Technology, 11, 35-46.

Thorne, S. L., \& Reinhardt, J. (2008). "Bridging Activities", new media literacies, and advanced foreign language proficiency. CALICO Journal, 25(3), 558-572.

Tschukin, A. N. (2004). Obuchenie inostrannym yazykam: Teoriya i praktika. Moscow, 416.

Vaisburd, M. L. (2003). Tipy zadach v obuchenii inoyazychnoj rechevoj deyatelnosti. Razvitie poznavatelnoj aktivnosti v protsesse ovladeniya rechevoj deyatelnostyu na inostrannom yazyke. Moscow, 186.

Zaretskaya, E. N. (2002). Ritorika: Teoriya i praktika rechevoj kommunikatsii. Moscow, 480.

Zimnyaya, I. A. (2007). Pedagogicheskaya psikhologiya. Moscow, 384.

Клычникова, Z. I. (1973). Psikhologicheskie osobennosti obucheniya chteniyu na inostrannom yazyke. Moscow, 278.

Obnosov, N. S. (2012). K voprosu o soderzhanii ponyatiya nepodgotovlennoj rechi i klassifikatsiya uprazhnenij, napravlennykh na eyo razvitie. Inostrannye yazyki $v$ shkole, 4, 102-107. 


\section{Copyrights}

Copyright for this article is retained by the author(s), with first publication rights granted to the journal.

This is an open-access article distributed under the terms and conditions of the Creative Commons Attribution license (http://creativecommons.org/licenses/by/3.0/). 